\begin{tabular}{|c|c|c|}
\hline & Int.J.Curr.Microbiol.App.Sci (2021) 10(09): $473-483$ & \multirow{4}{*}{ 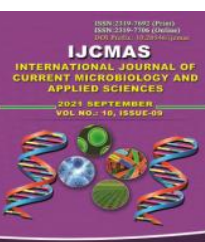 } \\
\hline & \multirow{4}{*}{$\begin{array}{l}\text { International Journal of Current Microbiology and Applied Sciences } \\
\text { ISSN: 2319-7706 Volume } 10 \text { Number } 09 \text { (2021) } \\
\text { Journal homepage: http://www.ijcmas.com }\end{array}$} & \\
\hline & & \\
\hline \begin{tabular}{|l} 
EXCELLENT \\
\end{tabular} & & \\
\hline PUBLIS & & www.ijemas.com \\
\hline
\end{tabular}

\title{
Identification of Native Microorganisms of the Amazon Rhizosphere to Speed up the Decomposition Process of Agro-Industrial Organic Waste
}

\author{
Ocampo-Guevara, Jhon-Alexander*, Vega-Espinoza, Johana-Jazmín, \\ Rivera-González, Johanna-Rivera and Carlos Jacome \\ Universidad Estatal de Bolívar, Facultad de Ciencias Agropecuarias y del Ambiente. Carrera \\ de Agroindustria. Guaranda - Ecuador \\ *Corresponding author
}

A B S T R A C T

Keywords

Inoculum;

Microorganism,

Aerobic bacteria,

Mushrooms

Article Info

Accepted:

20 August 2021

Available Online:

10 September 2021
Agribusiness is one of the areas with the greatest impact, which, due to the processes involved within this area, generates waste that, given its composition, is used in optimal materials to be used for degradation methods in the production of composting, different microorganisms such as Pseudomonas, Bacillus, Aspergillus help in the decomposition of waste from agribusiness, the metabolic activity of these microorganisms allows the degradation of animal and plant tissues such as cellulose, starch, pectin, proteins, agar that intervene in nitrification and nitrogen fixation processes, for the degradation process it is necessary to carry out in composting beds of organic waste isolated with strains of the rhizosphere from the natural forest of CIPCA the strains use the dimensions of $4 \times 1 \times 1$ giving a city layer of $4 \mathrm{~m} 3$ or about $640 \mathrm{~kg}$ of organic rough which are covered with geo mucosa, surrounded by gutters to collect leachate two produced by the effect of degradation, this process of degradation of organic matter allows to obtain a product with characteristics such as earthy odor, texture and uniform structure, where a $\mathrm{pH}$ close to neutral was registered in the control beds, gradually increasing from that moment with slightly alkaline values where it does not present characteristics of the initial organic matter, reducing the volume by $35 \%$, for this the objective is to maintain Controller of certain parameters of temperature, humidity, $\mathrm{pH}$, compost ratio and organic matter content.

\section{Introduction}

The Ecuadorian agribusiness represents an important sector of participation for the economy. Its operation generates waste that, given its composition and possibility of processing (Maldonado, 2018), becomes a material of interest to be used for agroindustrial waste and waste has originated the method and their degradations (Naranjo, 2018). Composting is an exothermic aerobic biological process in which microorganisms biologically decompose and mineralize an organic substrate, achieving a stable final 
product, free of pathogens and seeds (ARIAS, 2017), which can be beneficially applied to the soil is a process aerobic bioxidative in a controlled environment that produces compost, $\mathrm{CO}_{2}$, water, heat and sanitization of the compost. (Tortosa, The composting process, key points, 2017), currently this transformation consists of several processes that have a variable permanence, restricted by climatic factors, waste aptitude, their size, humidity and aeration in the biological composition (Henry, 2019). These fermentation beds made in the same place of the controlled dump (Cortina, Taype \& Ore, 2020) and the transformation time ranges between 92.50 days and 107.00 respectively, which implies a granacope of material in the composting plant (Cherres, 2017). The compost is an organic- natural conditioner that has allowed us to improve the physical, chemical and biological properties of the floors, such as their structure and consistency, in the medium and long term, increasing the cationic exchange capacity, buffer capacity, the concentration of some essential nutrients and the biological activity of the soil (Ospina, 2016). The Organic Law of Higher Education (LOES), in its article 8, literal, states that we must promote and execute research programs of a scientific, technological and pedagogical nature that contribute to the improvement and protection of the environment and promote composting as the best method to take advantage of organic waste and improve soils focusing on organic agriculture for the development of small farmers (Sanmartín \& Zhigue, 2017).

At present, the Ecuadorian industry is a very important entity in economic participation, which derives waste and at the same time gives the possibility of converting it into useful material for agribusiness since biologically they have a high degree of productivity of course, to reach extract the maximum potential, microorganisms need a series of processes. Composting is one of them which is an exothermic aerobic biological process in which microorganisms are biologically decomposed and result in the mineralization of the components.

\section{Development of the Topic}

\section{Agribusiness waste}

Agribusiness has the ability to promote global economic, social and environmental development, as long as it maintains a balance between the activity carried out and the protection of the environment in each of its processes (Vargas \& Pèrez, 2018), waste or by-products are generated in any production process and are usually not of later use as raw material for the production chain, this agroindustrial division is no exception, since it generates waste that can be defined as solid or liquid stage materials obtained from the direct consumption of primary products or their industrialization that are no longer useful for the process that generated them, but can be exploited or transformed to achieve another product with economic, productive or social value, each subsector of the agro-industry generates specific waste, mostly, these present optimal characteristics for their benefit in another production chain or as a method solution or recovery of some contaminated intermediate (Vargas \& Pèrez, Use of agroindustrial waste to improve the quality of the environment, 2018).

There are many agroindustrial activities that generate residues either at the main level, the farmer, or livestock production or in processes of revolution with raw materials of living origin, this has motivated different institutions to carry out projects or research aimed at promoting the use of the Generating different benefit alternatives that have been studied and implemented, corresponding to some research and project initiatives to use added value to 
said waste (Curry et al., 2017). Each point of the agro-industry has its specific wastes, most of which have the potential to be used optimally in another production chain or as an option to avoid environmental contamination, since if these wastes are not treated correctly, they are a waste pump time did the environment. Farmers or industrial producers are the entities that are immersed in the main line of generating waste or in the revolution of raw material of living origin, this has given way to the motivation of research or projects that try to make the most of the waste left by the industry or the same farmer with incredible benefits, and thus be able to add value to the waste already processed.

\section{Identification of selected microorganisms for waste degradation}

When the selected strains were identified, the production of secondary metabolites such as alpha-amylase produced by Pseudomonas and bacillus was considered by considering the high metabolic and agronomic capacity previously observed by research in the area and published by various authors, the production of secondary metabolites such as alpha-amylase produced by Pseudomonas and bacillus, which, in addition to extrapolar proteins, it produces starch proteins that contribute to cell proteins, as well as the extra starch proteins that contribute to glycilli and bacillus. nucleic acids and lipids that are secreted in the genus bacillus, allow the microorganism to use these products for their degradation (Miranda, 2019).

According to (Rivas, 2019) some species of Bacillus and Pseudomonas have the enzymatic capacity to degrade diverse components before the cell wall of certain mushrooms, in the Bacillus presents spores with high resistance to physical agents that constitute a way of counteracting the environmental stress, its development ecology once the substratum is active, and once the substratum is active, and once the substrates are active, with substratum availability, where it is active, once the substrates are active, and once the soil is active. The resource starts the formation of spores to be able to winter.

Its metabolic activity allows grading a large amount of animal and vegetable tissues such as cellulose, starch, pectin, proteins, agar, intervening in the nitrification and nitrogen fixation processes. Being an essential part in the carbon and nitrogen cycles, the selected bacteria have the ability to decompose the organic matter, forming the pathogens or antagonists of the organic acids, which interfere with the microorganisms or antagonists of the alkaline agents (Moreno, 2019).

By finding the strains that we selected they allowed us to visualize the respective potential of each one of them and determining the high percentage of metabolic and agronomic capacity according to some species of bacillus and Sudamines have the ability to reach a better result, the identification of microorganisms is the basis for future crop production to be much more efficient.

One of the requirements for it to be a high quality microorganism is in the waste that is being used and the correct management of the beds since they have their temperature and humidity so the molecules of the phenotypes will be able to give a better result against the demand required by a consumer of any product

\section{Composting beds for the degradation of organic waste}

In the solid organic waste composting beds, a limestone platform covered with geo-mucosa was placed, surrounded by gutters to collect the leachate from the cause of disintegration, 
which are manufactured with the dimensions of $4 \times 1 \times 1$ giving a capacity of $4 \mathrm{~m} 3$ or about $640 \mathrm{~kg}$ of organic waste, prior to its alignment all the material was subjected to Grinding in a hammer crusher with $4 \mathrm{~cm} 3$ screening to obtain particles between 1 to $3 \mathrm{~cm} 3$ size convenient to speed up the migration of microorganisms and the ventilation for their first decomposition process, to authenticate and inspect the process an automatic flipping was carried out weekly (Toloza \& Lizarazo, 2018).

The composting beds of solid organic waste proceeded to put a layer of lime since it is a natural disinfectant, covered with mucosa around it contains gutters which help to collect the leachate that produces disintegration the collars are made with the dimensions of $4 \times 1$ $\mathrm{x} 1$ that result in a capacity of $4 \mathrm{~m}$ or about $65 \mathrm{~kg}$ of organic supply, the material that was used is total waste and thus obtain the corresponding particles to carry out this process, it is necessary to water so that it has enough humidity and decomposition is achieved in a better way, and flipping from the bottom out.

\section{Preparation and inoculation of microorganisms in composting beds}

From each of the strains isolated in rhizosphere from the natural forest of CIPCA, we made an initial selection of those that showed greater amylolytic and cellulolytic activities in accordance with the degradation halos obtained in the crops (Ruiz, 2019). To do this, an assessment of the amylolytic and cellulolytic capacity of 20 bacterial strains is carried out, of which 10 were selected for presenting the greatest degradation halo in the same way, we assessed the dadamylolytic and cellulolytic activity of 10 fungal strains of which, the two most active strains were selected, adding a total of 12 strains (Guzmán \& Zambrano, 2018), this selection was established by descriptive statistics that determined a $95 \%$ reliability using them at dehydrolysis greater than or equal to $0.5 \mathrm{~cm}$ in diameter, which ruled out micro-organisms with very low gravitational activity in the middle inoculated (Meza \& Fukus, 2019).

The selected microorganisms do not show a deviation from mutual inhibition in the work developed in a solid medium confirmed in the data of progress of the development curve in a liquid medium carried out in their own and combined way (Gomez, 2018).

On the other hand, the mushrooms cultivated in the medium Lactrimel were collected by means of flooding, waiting for them with physiological solution, adjusting its concentration to $1 \times 107$ with the help of the spore counting chamber, for each selected inoculum, a concentration of 1 x 107 in saline solution was prepared, this in addition to compost data obtained in the previous works to have a decomposer in the previous works (Salazar, 2018).

To carry out these tasks, the help of the MAYWET Ar75 tumbling machinery and its incorporation of the microbial content, with a concentration of $1 \times 10^{7} \mathrm{CFU} / \mathrm{ml}$ per strain, with a content of 4 liters of the solution per cubic meter of organic matter, is necessary (Barrena, 2017). From each of the strains that were obtained from the rhizosphere of the Amazon forest, a very strict selection was made to be able to take the ones that would contribute the highest percentage in our activity to develop

\section{Control and evaluation of the beds without hidden with the microorganisms}

Each of the variables considered in this study, such as electrical conductivity, $\mathrm{C} / \mathrm{N}$ ratio, cationic exchange capacity, moisture content, temperature, $\mathrm{pH}$, were determinants to observe 
the maturity and stability of the final product indicated in the production regulations for Fermented Organic Fertilizers, but we must consider that these solutions for each one of these parameters and each one of them present a common pattern maturity. (Muñoz, 2019)

These microorganisms help in the course of disintegration of organic materials and produce organic acids (Morales, 2020) as shown in the following table.2.

\section{Temperature of the compost}

The temperature variable shows the amount and evolution of the micro-organisms in the psychrophilic, mesophilic and thermophilic stages of composting in the inoculated beds compared to the control, the delta of temperatures was reached in 8 with a value of $65^{\circ} \mathrm{C}$ reaching a higher stability which allows to demonstrate the active metabolic processes. (Dominguez, 2019)

\section{Compost moisture}

Once a final maturity silhouette of each of the trials obtained a lower humidity of $40 \%$, coinciding with data reported by other investigations at the beginning of the process, it recorded a humidity of $65 \%$ and after 3 months it remained at $50 \%$, while $40 \%$ of final humidity was recorded in the process. Weeks 19 and 20 of the composting process in comparison of the control beds, this value was recorded in week 24 , this result was beneficial for the imination of micro-organisms with antigens.

As a result, no self-heating was recorded in the beds after week eight, known as a period of stabilization according to previous authors, these microorganisms show resistance to changes in temperature and $\mathrm{pH}$, which ensures permanence within a metabolically active microbial population. We verified in a new re- isolated its permanence in the composting beds in the three moments of the processes (Vaca, 2017).

Undoubtedly, temperature has played an important role in the compost process since the psychrophilic, mesophilic and thermophilic stages of composting the beds since it requires the necessary humidity for the degradation of the waste that is there. They find and give a superior stability of metabolic processes.

\section{pH of the Compost}

Both the inoculated beds and the control registered a slightly acidic $\mathrm{pH}$ at the beginning of the process, which was caused by the formation of simple organic acids originating in the initial stage of composition, the differences between the inoculated piles and the control increased slightly from the second week, where they were registered in the control beds with slightly closer to a near $\mathrm{H}$ values from that moment. The difference in $\mathrm{pH}$ recorded in the inoculated beds that rose slowly and gradually, during the first four weeks of the process, the $\mathrm{pH}$ in the inoculated piles was kept below that of the eight control piles, this was caused by the aeration obtained in the turning, which increased the degradation stage of decomposition of organic matter, as result of recorded neuter (Tortosa, 2020).

\section{Compost Relationship}

As the final product of the metabolic activity of the aerobic microorganisms of the waste beds losing volume of the material in the form of gas as $\mathrm{CO} 2$ and $\mathrm{H} 2 \mathrm{O}$, the mass was an important factor to control to obtain an adequate degradation.

In a composting process, it is essential to avoid high values of their ratio since a high 
ratio prevents micro-microbial development, due to limitations in nutrients and therefore the process is delayed (Tortosa, 2020).

In the composting beds register a trend towards the decline. With a $\mathrm{C} / \mathrm{N}$ ratio, it started at 30 and from the 4th and 5th week, there was a greater decrease in the inoculated beds, reporting in week 12 a value of 15 compared to the control, which was 17 values that were maintained at the end (Cabrera, 2017).

The final process of the activity of the aerobic metabolic microorganisms of the compost bins where the waste is found loses volume, forms gas such as $\mathrm{CO}_{2}$ and $\mathrm{H}_{2} \mathrm{O}$, the mass is one of the most relevant factors to be controlled and to be able to obtain an adequate reduction. The purpose of the composting process is to result in high values in relation to the production of microbial development because there is a low level of nutrients in the soils, therefore composting is a short and long-term development to reduce these deficits and help to the environment and the economy.

\section{Organic Matter Content}

The content of organic matter decreased with the passing of time or the composting process, recording the most in the first two months. As it was solid waste, a high value of $87 \%$ was started and after three months a value of $52 \%$ was obtained in the control piles and $63 \%$ in the inoculated ones, this proportion was maintained with some variations until the end of composting (Alvaréz, 2017). The contents of the organic matter left by the compost according to the time of the first recorded months. As they are solid products, the yard has a high value of $87 \%$ and after three months a value of $52 \%$ was obtained until the completion of composting.

Table.1 Composition of agro-industrial waste

\begin{tabular}{|c|c|}
\hline Waste & Composition \\
\hline Sugarcane bagasse & $50 \%$ cellulose, $25 \%$ hemicellulose and $25 \%$ lignin \\
\hline Banana peel and rachis & $\begin{array}{c}3 \% \text { starch, 1-2\% sugars in the shell (Hernández, 1986). The } \\
\text { rachis is made up of } 50 \% \text { of the dry biomass lignocellulose } \\
\text { resource }\end{array}$ \\
\hline Empty bunches of oil palm & $\begin{array}{l}\text { The empty bunch after pressing is composed of water } \\
29.95 \% \text {, residual oil } 2.41 \% \text { and fiber (lignocellulose) } 67.74 \%\end{array}$ \\
\hline Olote and dried hard corn husks & $\begin{array}{l}\text { The corn cob is made up of hemicellulose } 31.1-41.2 \% \text {, } \\
\text { cellulose } 30-50 \% \text { and lignin } 4.5-18.8 \% \text {. } \\
\text { The leaves of the corn cob have Holo cellulose } 78.86 \% \text {, } \\
\text { cellulose } 43.14 \% \text {, lignin } 23.00 \% \text { and ash } 0.76 \% \text {. }\end{array}$ \\
\hline Rice husk & $\begin{array}{c}\text { Composed mainly of cellulose } 33.81 \% \text {, lignin } 20.78 \% \text { and } \\
\text { hemicellulose } 15.94 \%\end{array}$ \\
\hline Banana peel and rachis & $\begin{array}{c}\text { The green banana peel has glucose, } 1.6 \% \text {, sucrose } 0.7 \% \text {, } \\
\text { fructose } 0.6 \% \text {, starch } 50.0 \% \text {, cellulose } 9.0 \% \text { and } \\
\text { hemicellulose } 12.4 \% \text {. The mature peel contains glucose } 9.0 \% \text {, } \\
\text { fructose } 19.0 \% \text {, sucrose } 2.2 \% \text {, starch } 35 \% \text {, cellulose } 10.5 \% \\
\text { and hemicellulose } 14 \% \text {. }\end{array}$ \\
\hline Orange peel and seed & The peel has $1.55 \%$ fat, $17 \%$ pectin and $3.8 \%$ neutral sugars. \\
\hline
\end{tabular}

Source: Riera, María Antonieta (2018) 
Table.2 Comparison of the biological treatment using micro algae and microorganisms

\begin{tabular}{|c|c|c|c|c|c|c|}
\hline & $\boldsymbol{\mu m a x}$ & $\begin{array}{c}\text { Organic } \\
\text { load }\end{array}$ & Biomass & $\begin{array}{c}\text { Substratum } \\
\text { (DQO/DBO5) }\end{array}$ & $\begin{array}{c}\text { Permissible } \\
\text { limits (COD) }\end{array}$ & $\begin{array}{c}\text { Allowable } \\
\text { limits } \\
\text { (DBO5) }\end{array}$ \\
\hline Microalgae & 0.2 & 3580 & 552.8 & 163.5 & 400 & 200 \\
\hline Microorganisms & 0.3 & 3580 & 644.9 & 276.8 & 400 & 200 \\
\hline
\end{tabular}

Source: Alice Morales, 2020

Table.3 Chemical analysis of composting

\begin{tabular}{|c|c|c|c|}
\hline Organic material & $\mathbf{6 5}-\mathbf{7 0 \%}$ & Relationship C/N & $\mathbf{1 0}-\mathbf{1 1}$ \\
\hline Humidity & $40-45 \%$ & Humic acids & $2.5-3 \%$ \\
\hline Nitrogen, as $\boldsymbol{N}_{2}$ & $1.5-2 \%$ & $\mathrm{pH}$ & $6.8-7.2$ \\
\hline Phosphorus, as $\boldsymbol{P}_{2} \boldsymbol{O}_{5}$ & $2-2.5 \%$ & Organic carbon & $14-30 \%$ \\
\hline Potassium, as $\boldsymbol{K}_{2} \boldsymbol{O}$ & $1-1.5 \%$ & & $2-8 \%$ \\
\hline
\end{tabular}

Source: Cajamarca, Diego (2012)

Fig.1 Composting process

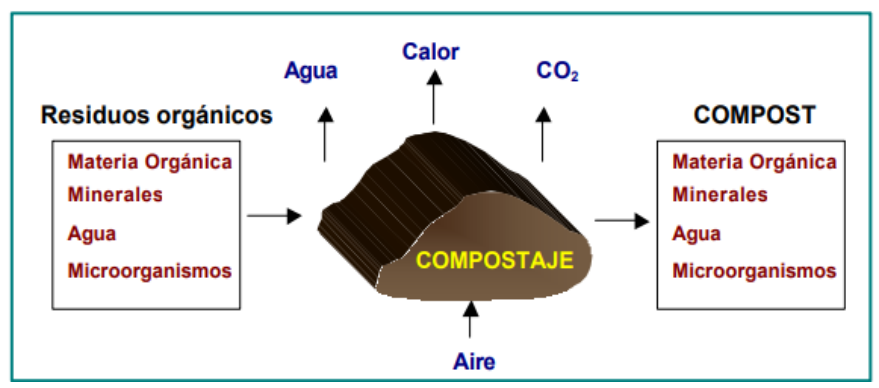

Source: Alcolea, Mirian (2017)

Fig.2 Stages of composting as a function of temperature changes

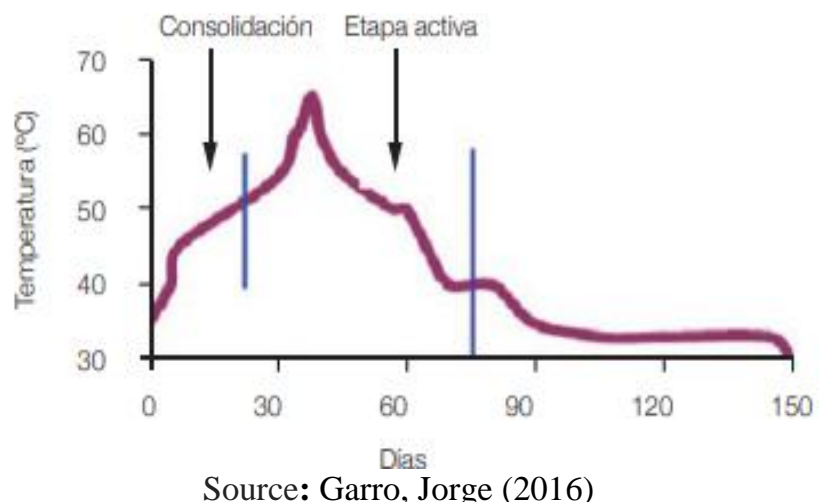


Fig.3 $\mathrm{pH}$ in the composting process

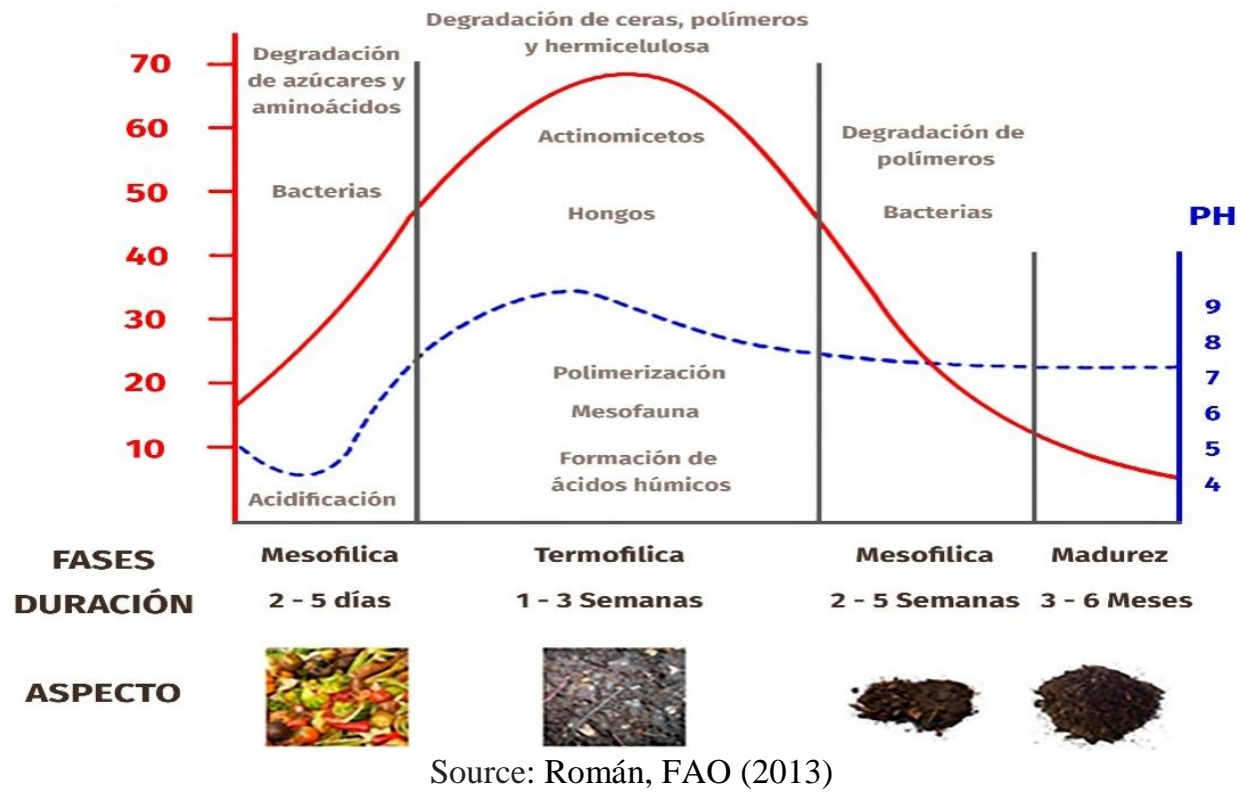

\section{Physical aspects of compost}

The product obtained at the end of the process presented characteristics such as earth color, texture and uniform structure, dark brown, neutral $\mathrm{pH}$, where it does not present characteristics of the initial organic matter, reducing its initial volume by $35 \%$. (Vázquez, 2018), according to (Barbaro et al., 2018) these components are less difficult, with respect to the mixing of the substrate, loaded in the containers and transfer, it is recommended that they have an apparent density.

The use of efficient microorganisms in agriculture depends on the surface, the quality of the soil, the temperature, the working methods and the irrigation, among other factors; with the application of microorganisms since the soil retains more water, which implies an improvement of the crops that increase their resistance to water stress in times of dry season or in more sandy soils; This advance is given both by the increase in organic matter on the surface, reducing porosity as a consequence of microbial activity, and by the ionic balance, thus favouring the interaction of the surface charges of the physical structure of the soil with the ionic charges of the soil, water (Morocho \& Mora, 2019).

The product that has given us at the end of the process presented the following characteristics such as the smell of earth, its texture and completely uniform structure with a dark tone and a neutral $\mathrm{Ph}$ in which it does not reflect characteristics of the organic matter that it presented at the beginning. It was reduced by $35 \%$ of its initial volume, but to be able to transport the substrate in a correct way, it depends on the quantity and density with which the mixing tasks were carried out.

While it is true that the use of microorganisms in the soil is one of the most efficient resources of the methods that are applied on the surface, and thus significantly improve the quality of the soil, the temperature, tillage methods and irrigation are some of the factors that determine that microorganisms help to 
make it a viable production since the soil retains more water than usual, which helps in the dry times of the year, and thus improving production and even in sandy soils, and strengthen the prosperity of the consequences by increasing organic matter and ionic balance.

The data given to us by the study made by the agro-industry has had a favorable impact on the economy of Ecuadorians, thanks to the agro-industrial processes that give way to many products that leave residues that are possibly harmful to the environment. environment, are used to achieve a better use of them and give an added value gives an effect of a better life for small and large producers and industries to commercialize organic fertilizers among others, composting is one of the most effective methods to condition organically waste

This process allows a medium and long-term improvement that takes advantage of the physical, chemical, biological properties of the soils and thus increase its level of productivity thanks to the microorganisms that are responsible for feeding the soil. The contributions made by the study agribusiness gives a primary impact to support the economy of Ecuadorians, due to their agroindustrial processes at the time of giving added value to products, these wastes can be degraded through composting which is an organic- natural conditioner that has allowed us to improve the physical, chemical and biological properties of soils in the medium and long term, such as their structure and consistency, increases the cation exchange capacity, capacity, and buffer concentration of some nutrients. Some nutrients and the activity Soil logic, through the use of microorganisms found in the rivers spheres of the Amazon rivers, which indicate a longer degradation time in the composting beds.

\section{References}

Arias, A. (Febreo De 2017). Los Microorganismos En Los Abonos Orgánicos A Partir De Podas. Colombia.

Arias, C. E. (Agosto de 2018). Los Microorganismos En Los Abonos Orgánicos. Los Microorganismos En Los Abonos Orgánicos. Colombia.

Ballesteros, T. M., \& Hernández, C. (EneroMarzo de 2018). Crecimiento Microbiano En Pilas De Compostaje De Residuos Orgánicos Y Biosólidos Después De La Aireación. Microbial Growth in Compost Piles of Organic Waste and Biosolids after the Aeration Process. Mexico : Yailet bernas Carvajal.

Barbaro, L., \& Karlanian, M. (Enero-Marzo de 2017). Importancia del pH y la Conductividad Eléctrica (CE).

Barrena, G. R. (2017). Inoculación de las camas de compostaje Inoculación de las camas de compostaje Inoculación de las camas de compostaje. Inoculación de las camas de compostaje, 25.

Bueno, M. P., \& Díaz, B. M. (2018). Factores que afectan al proceso de Compostaje.

Cabrera, C. F. (2017). Factores que afectan al proceso de Compostaje.

Carmona, P. N. (23 de Noviembre de 2017). Procesos de compostaje. Santiago de Caly.

Cherres, N. (26 de Marzo de 2017). Transformación De Desechos Orgánicos En Compost. Transformación De Desechos Orgánicos En Compost. Ambato, Tunguragua, Ecuador.

Cotrina, G., Oliver, T., \& Franklin, O. (2020). Manejo integral de residuos sólidos para minimizar la contaminación del ambiente en el distrito de Panao, Huánuco, Perú*. Javeriana, 4.

Cury, K., Aguas, Y., Martinez, A., Olivero, R., \& Chams, L. (2017). Residuos agroindustriales su impacto, manejo y aprovechamiento. Revista colombiana de ciencia animal, 11.

Dominguez, E. (11 de Octubre de 2019). 
Temperatura del compost.

Escobar, J., \& Sánchez, M. (2016). Evaluación del proceso de compostaje con diferentes tipos de mezclas basadas en la relación $\mathrm{C} / \mathrm{N}$ y la adición de preparados biodinámicos en la Granja Modelo Pairumani. scielo, 10.

Escobar, N. M. (24 de Agosto de 2016). Identificación De Poblaciones Microbianas En Compost De Residuos Orgánicos De Fincas Cafeteras De Cundinamarca. Identification of Microbiological Populations. Medenlling, Colombia.

Escudero de Fonseca, A. A. (18 de Febrero de 2016). Los Microorganismos En Los Abonos Orgánicos A Partir De Podas En La Universidad Norte De Colombia. Colombia, Barranquilla, Colombia.

García, A., \& Herrera, M. (Septiembre de 2017). Propiedades de un compost obtenido a partir de residuos.

Gómez, Y. T. (2018). Microorganismos presentes en el compost. Importancia de su. Revista electrónica de la Agencia de Medio Ambiente, 9.

Guzmán, Á. M., \& Zambrano, D. (Enero-Marzo de 2018). Aislamiento Y Selección De Bacterias Autóctonas De Manabí-Ecuador Con Actividad Celulolítica. 12. Manabi, Ecuador.

Guzman, J. (2017). Resultados De Aplicación De Compost Urbano De Calidad En El Sector Forestal.

Henry, I. A. (12-15 de Noviembre de 2019). La Biotecnología Como Elemento Clave De La Transformación Hacia Sistemas Agroalimentarios Sostenibles. $X$ Encuentro Latinoamericano Y Del Caribe De Biotecnología. Uruguay, Argentina: serie tecnica 523.

Laconte, M. C. (2019). La importancia de producir compost. Scielo, 7.

Laich, F. (21 de Octubre de 2017). Los microorganismos en el proceso de compostaje. Experiencias de fertilización orgánica en platanera.

Laich, F. (13 de Octubre de 2020). Los microorganismos en el proceso de compostaje. scielo, 19.

Maldonado, S. (2018). Residuos Agroindustriales Generados En Ecuador. latindex, 5.

Masabni, J. G., \& Lillard, P. (Abril de 2019). Materiales para compostar. Compostaje Composta.

Meza, V., \& Fukusaki, A. (Julio-Septiembre de 2019). Aislamiento Y Selección De Microorganismos. Aislamiento $Y$ Selección De Microorganismos. Lima, Peru.

Miranda, J. (18 de junio de 2019). El compost, temperatura y humedad. Latacunga, Ecuador.

Morales, A. (2020). Comparación de tratamientos biológicos usando microalgas y microorganismos en aguas residualesde empacadora de pescado mediante simulación de procesos. Universidad de Guayaquil, Guayaquil. Obtenido http://repositorio.ug.edu.ec/bitstream/redu g/51462/1/BINGQ-IQ-20P52.pdf

Moreno, M. V. (2019). Compostaje de residuos cítricos. Scielo, 10.

Morocho, M., \& Mora, M. (2019). Microorganismos ecientes, propiedades funcionales $\mathrm{y}$ aplicaciones agricolas. centro agricola, 11.

Muñoz, P. A. (14 de Abril de 2019). Resultados obtenidos en las experiencias piloto de compostaje. Medelling, Colombia.

Nacimba, G., \& Santafé, S. D. (27 de Julio de 2018). Tratamiento de desechos orgánicos empleando. Artículo Original.

Naranjo, P. I. (12 de septiembre de 2018). Aplicación De Microorganismos Para Acelerar. Trabajo De Investigación Estructurado De Manera. Ambato, Ecuador.

Ospina, I. (2016). Influencia de la aplicación de ompost producido a partir de residuos de la caña de azucar Saccharum officina en un Vertisol del Valle del cauca. Universidad Nacional de Colombia, Palmira.

Pérez, M. A. (Junio- Noviembre de 2019). Manual de Compostaje. Ecuador. 
Pérez, R. F., \& León, Q. J. (2019). Actinomicetos aislados del compost. Actinomicetos aislados del compost. Rev. mex. fitopatol vol.33 no.2.

Pillco, M. K. (2020). Evaluación Del Proceso De Compostaje De Residuos Orgánicos, Aplicando Microorganismos Eficaces. Peru.

Ramos, A. D., \& Elein, T. (2017). Generalidades de los abonos orgánicos: Importancia del Bocashi como alternativa nutricional para suelos y plantas. Scielo, 7.

Rodríguez, L. A., \& Llenque, L. $(9$ de septiembre de 2016). Aislamiento y selección de bacterias celulolíticas a partir de compost de residuos orgánicos. Aislamiento y selección de bacterias celulolíticas a partir de compost de residuos orgánicos. Vol.36.

Ruiz, P. (05 de Enero de 2019). Importance of Soil Microorganisms. Ambato, Tunguragua, Ecuador.

Salazar, T. (12 de Noviembre de 2018). Actividad microbiana en el proceso de compostaje aerobio de residuos sólidos orgánicos. Lima, Peru.

Sanmartín, G., \& Zhigue, R. (2017). El Reciclaje: Un Nicho De Innovación Y
Emprendimiento Con Enfoque Ambientalista. Universidad y Sociedad.

Sztern, D., \& A, M. (2018). Manual Para La Elaboracion De Compost Bases Conceptuales Y Procedimientos. Scielo, 12.

Tortosa, G. (13 de marzo de 2017). El proceso de compostaje, puntos clave.

Tortosa, G. (14 de febrero de 2018). La humedad influye más en la actividad microbiana del compost que su temperatura.

Tortosa, G. (21 de Diciembre de 2020). El pH durante el compostaje. El pH durante el compostaje.

USA, E., \& Fundases. (2019). Manejo de Camas., Costa Rica.

Vargas, Y., \& Pèrez, L. (2018). Aprovechamiento de residuos agroindustriales para el mejoramiento de la calidad del ambiente. Facultad de Ciecias Basicas, 2.

Vargas, Y., \& Pèrez, L. (2018). Aprovechamiento de residuos agroindustriales para el mejoramiento de la calidad del ambiente. Revista Facultad de Ciencias Básicas, 14.

\section{How to cite this article:}

Ocampo-Guevara, Jhon-Alexander, Vega-Espinoza, Johana-Jazmín, Rivera-González, Johanna-Rivera and Carlos Jacome. 2021. Identification of Native Microorganisms of the Amazon Rhizosphere to Speed Up the Decomposition Process of Agro-Industrial Organic Waste. Int.J.Curr.Microbiol.App.Sci. 10(09): 473-483. doi: https://doi.org/10.20546/ijcmas.2021.1009.055 